\title{
مخاوف النازهين العراقيين وعلاقتها بالصراع النفسي
}

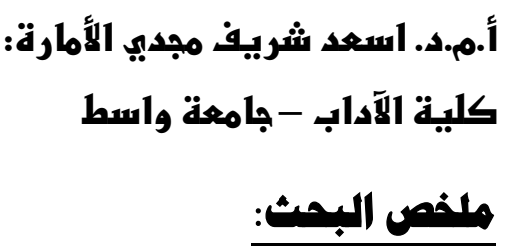

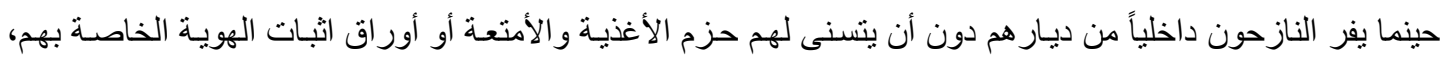
غالباً ما يتم ذلك تحت ظروف خطيرة بسبب الصدمة والعنف، لذلك قد بصبح النازحون داخلياً عرضة للمخاطر بشكل خاص ويحتاجون إلى المساعدة الإنسانية و الحماية. وعلى الرغم من أن السلطات الوطنية هي في صميم أي استجابة للنزوح الداخلي، إلا أنها قد نكون غير قادرة على تلبية احتباجات النازحين داخلياً بسبب أعدادهم الكثيرة، هدف البحث إلى: - قياس مستوى المخاوف لاى عينة البحث وفي ضوء فئ متغير الجنس. - قياس مستوى الصراع النفسي لدى عينة البحث وفي ضوء متغير الجنس.

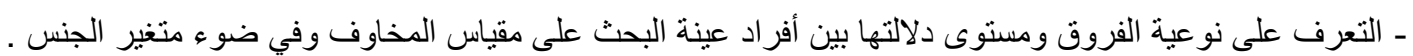
ـ التعرف على نوعية الفروق ومستوى دلالتها بين أفر اد عينة البحث على مقياس الصر اع النفسي وفي ضو هو متغير الجنس.

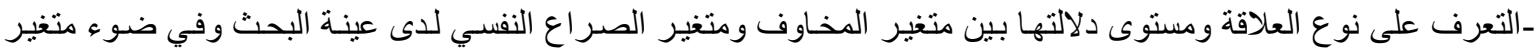
الجنس.

تَكون مجتمـع البحث من النـازحين مـن محافظـة "نينـوى" بـالعر اق إلى محافظـات كرستان العراق"أربيل وسـوران"

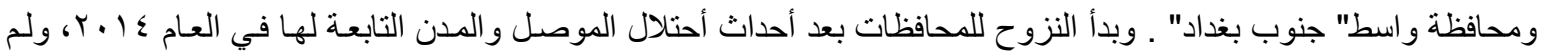
تتوفر البيانات الدقيقة عن أعداد النازحين لصعوبة حصرهم في أماكن محددة. أستخدم مقباسي المخاوف الثاملة ومقياس الصراع النفسي بعد أجر اء التقنين لهما على عينة عر اقية وتم تطبيقه على عينة البحث الحالي وتوصل إلى النتائج التالية:

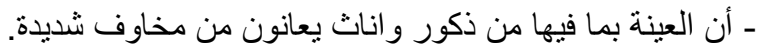

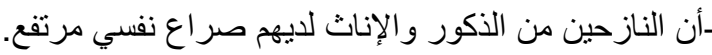

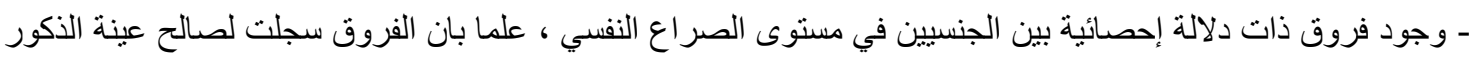

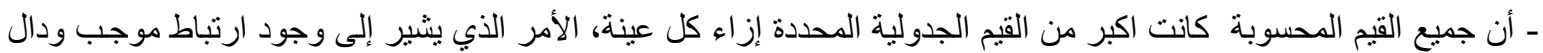
إحصائيا بين متغير المخاوف ومتغير الصراع النفسي لدى عينة البحث من النازحين ولكلا الجنسين.

\section{Abstract}

When internally displaced people get away from their homes without being able to packs food and luggage or their identity papers, often this takes place under dangerous conditions due to trauma and violence. So the internally displaced people may become vulnerable are particularly in need of humanitarian assistance and protection.

Despite the fact that the national authorities are at the heart of any response to internal displacement, but it is, they may not be able to meet the needs of internally displaced because of their great number

The objective of this research is to:

-Measure the level of Phobia in the research sample in light of gender variable.

-Measure the level of psychological conflict in the research sample in the light of the gender variable.

-Understand the specific differences and the level of significance of the research sample on the Phobia scale in light of the gender variable.

-Recognize the specific differences and the level of significance of the research sample on the psychological conflict scale in light of the gender variable

-Identify the type of relationship and the level of significance between Phobia and psychological conflict variables in the research sample in light of the gender variable.

Research community is of displaced people from the province of "Nineveh" in Iraq to Erbil and Soran in Iraqi Kurdistan, and Wasit province, "south of Baghdad". 
The decampment began to the provinces after the events of the occupation of Mosul and its subsidiary cities in 2014, and there is no accurate data on the numbers of displaced people due to the difficulty to confine them in specific places. Comprehensive Phobia scale and Psychological conflict scale were used after conducting adjustment for these two scales on Iraqi sample, and was applied to a sample of current research. The author has come to the following conclusions:

-That the sample research, including male and female suffering from serious fears.

-That the displaced male and female have a high Psychological conflict.

-The presence of statistically significant differences between the genders in the level of psychological conflict, noting that the differences are recorded in favor of the male sample.

-That all calculated values were greater than the tabular values that were specified about each sample, which indicates a positive and statistically significant correlation between Phobias variable and psychological conflict variable for the research sample of the displaced people and for both genders.

\section{هقدمة:}

يعد النزوح من الظواهر التي عُرفت منذ قديم الزمان في المجتمعات الإنسانية، حملت معها آثار نفسية

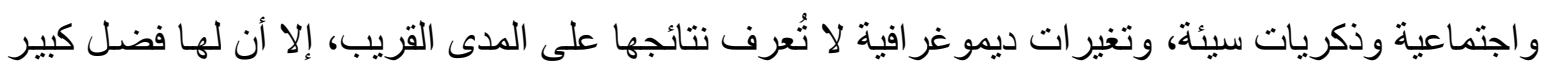

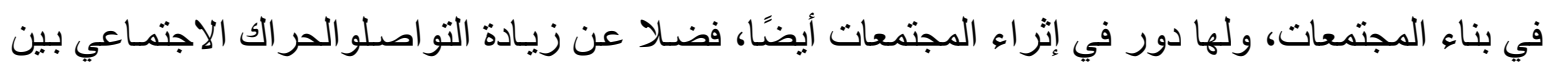

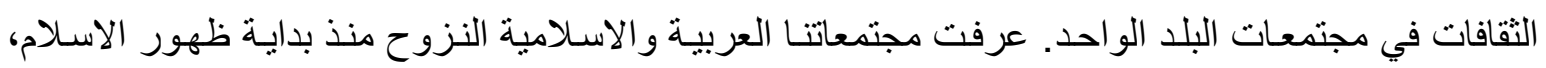

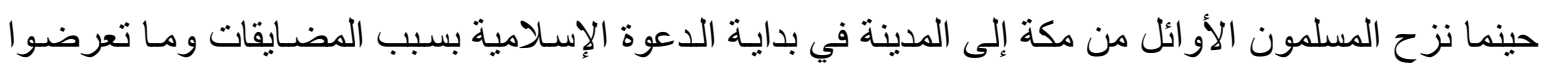

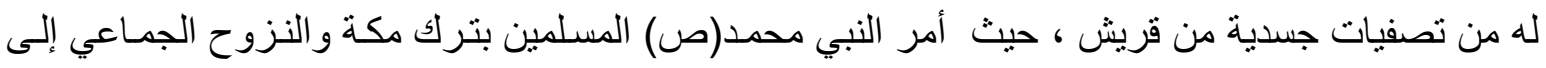

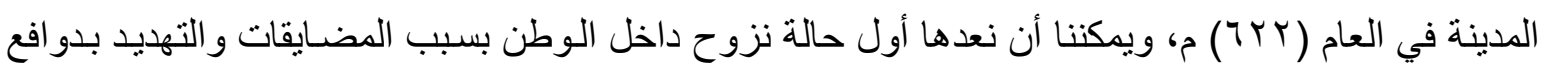

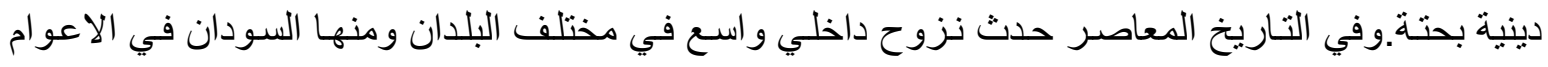

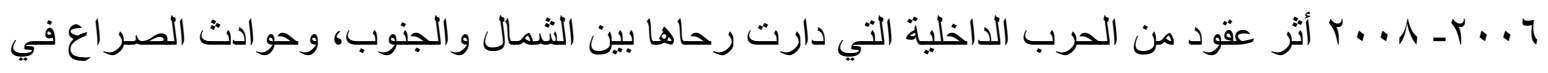

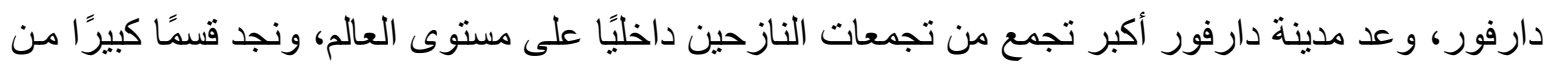

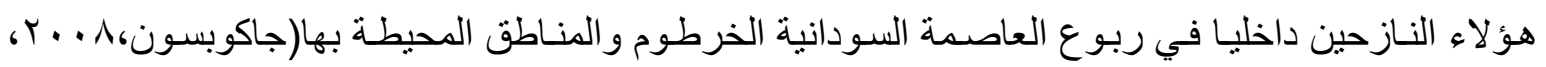

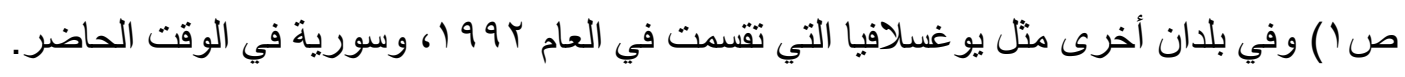

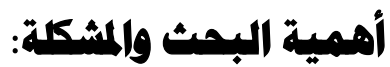

إن النزوح الجمعي لأقوام عاشت وترعرت في بيئة منذ ألاف السنين، يعد مشكلة كبيرة، هذا النزوح نتج عنه:

$$
\text { إهنزاز في الإنتماء للوطن }
$$

تدهور الصحة الجسمية والنفسية الجمعية

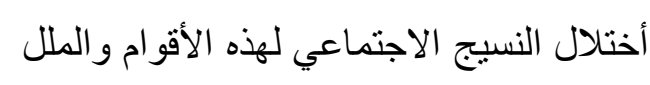

القلق و الإجهاد و الضغوط النفسية الجديدة التي ستنجم عن هذا النزوح.

تعـد تجربـة التهجيـر و الاضـطر ار للعـيش كرهـاً في المنفـى، نتيجـة للقهـع أو الحـروب أو الكـوارث الطبيعية، سمة من السمات الفاصلة في تاريخ البشرية، ويبقى النزوح القسري واحداً من العواقب الأكثر

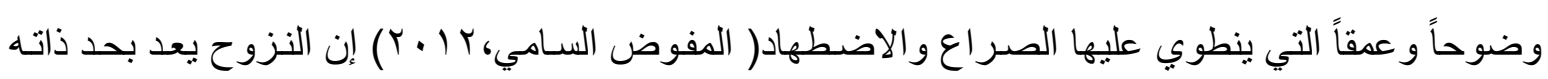
مشكله، وترك الاستقر ار والارتحال من الموطن الأصلي حتى وإن كان داخل الوطن أزمة حقيقيـة، فالارتحال أو النزوح القسري يعد أقسى و أكثر تدميرًا للفرد و أسرته، لذا فإن مشكلة البحث هي في في تعدد مصنسادر الخطر 


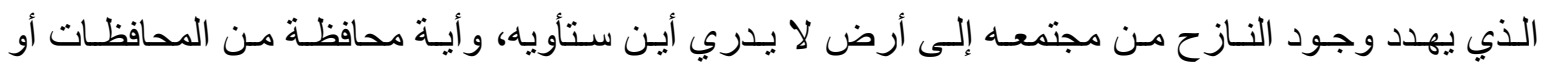

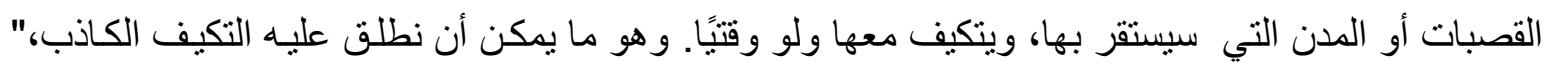

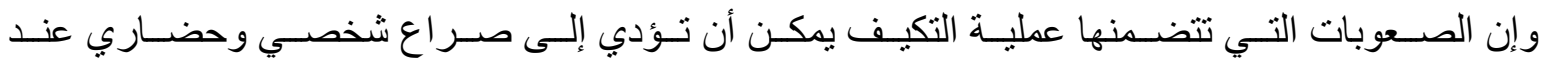

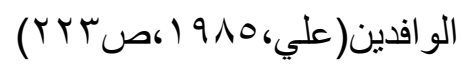

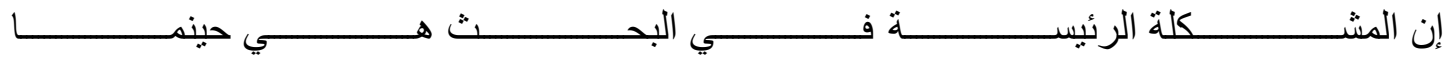

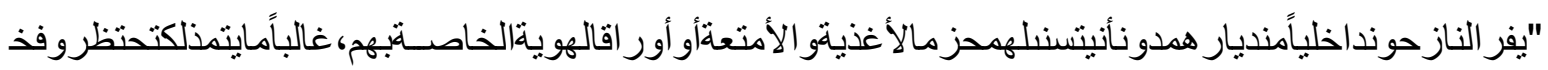
طير ةبسببالصدمة العنف، لذلكقديصبحالناز حو نداخلياً عرضة للمخاطر بشكلخاصو يحتاجونإلالمساعدةا لإنســانيةو الـ حمايس و علنالر غممنأنالسلطاتالو طنية هيفيصميمأياسـتجابةللنزو حالداخلي، إلأنهاقدتكو نغير قادرة علنتلبية|حتياجاتالناز حيندا

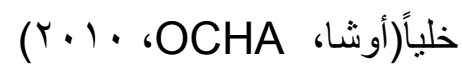

أن أهمية البحث الحالي تعد مرتكز لبداية دراسة رائدة في سيكولوجية مجتمع النازحين، تقتضي شينًا من المشقة والجهد، لا بسبب أعداد العينـة وكثرتهم فحسب، بل في المتغيرات النفسية التي تتعلق بـأحوال النازحين، فجدة الموضوع وكثرة المتغيرات المتعلقة به وتنوعها، قد تغري الباحثين بتجاوز المشقة، وتنوع النازحين من حيث انتماءاتهم القومية والدينية و المذهبية، حيث من ضمن عينة البحث الحسالي هم من الاكر اد و العرب، من المسيحيين و المسلمين، السنة والثيعة، الأيزيديين والثبك. ومن الأهمية النظريـة الأخرى أيضًا هو حيوية الموضوع فضلا عن إضافة التر اكم المعرفي عن التغييرات القيمية في تكوين المجتمع و وتداخله مـع المكونات الجديدة "النازحين".

ومن الأهميـة الميدانيـة في هذا البحث في النتائج التي يؤمل أن تسفر عنها، وربمـا تسهم في أتخـاذ الإجر اءات العمليـة لخدمـة النـازحين، من ناحيـة الخدمات النفسية والاجتماعيـة والإرشـادية، ووضـع البرامج الجديدة والاستفادة مـن تجـارب الثـعوب التـي مـرت بكوارث النزورح، ومـا نتجـت عنه مـن متغيرات غير متوقعة. أهداف البحث: يهدف البحث إلى : ـ قياس مستوى المخاوف لاى عينة البحث وفي ضوء متغير الجنس. ـ قياس مستوى الصراع النفسي لاى عينة البحث وفي ضوء متغير الجنس. ـ التعرف على نوعية الفروق ومستوى دلالتها بين أفراد عينـة البحث على مقيـاس المخـاوف وفي ضوع

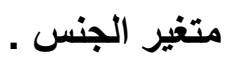
ــ التعرف على نوعية الفروق ومستوى دلالتها بين أفراد عينة البحث على مقيـاس الصراع النفسي وفي ضوء متغير الجنس. ـ التعرف على نوع العلاقة ومستوى دلالتها بين متفير المخاوف ومتفير الصراع النفسي للاى عينة البحث وفي ضوء متغير الجنس . 
الفرض الأول: لا توجد فروق ذات دلالة إحصائية بين منوسط درجات الذكور ومتوسط درجات الإناث على مقياس المخاوف. الفرض الثاني: لا توجد فروق ذات دلالة إحصائية بين متوسط درجات الذكور ومنوسط درجات الإنات على مقياس الصر اع النفسي. الفرض الثالث: لا يوجد ارتباط ذو دلالة إحصائية بين متغير المخاوف ومتغير الصـراع النفسي لدى عينـة البحث وفي ضو و متغير الجنس.

حدود البحث: أقتصر البحث الحالي على النازحين من محافظة نينوى"مركز الموصل" و الأقضية والنواحي

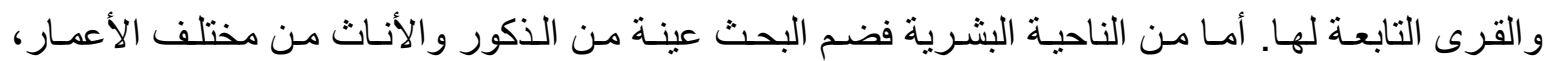
تراوحت من · r ـ. - سنة. ومن مختلف الأديان و الطو ائف و الملل، وهم من الثبك والايزيديين، و المسلمين" السـنة والثـيعة" و المسيحيين، ومـن العـرب و الأكراد. تـم التطبيـق النهائي للبحـث مـن المـدة (تشـرين الثاني

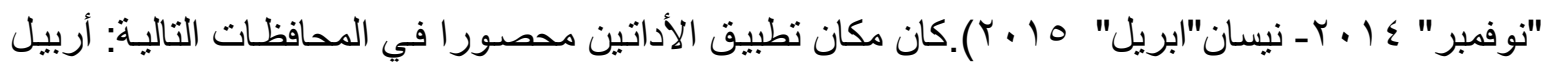
وسوران في كردستان العر اق ومحافظة واسط.

تمديد الإمhات:

المخاوف: Phobias المخاوف المرضية عبارة عن مخاوف شديدة ضـاغطة تتصل بموقف معين أو شيء معين، و عـادة مـا تكون درجـة الخوف المرضـي أشـد مما يتطلبـه الموقف الذي يثير الخوف(ويتنج، 19VV

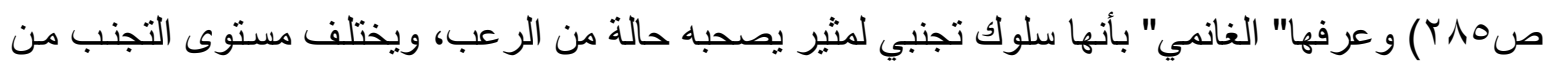

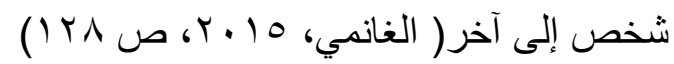
النازح:في معجم المعاني الجامع والمعجم الوسيط: نزح الثخص عن أرضه: بعد عنها. السكان النازحون عن

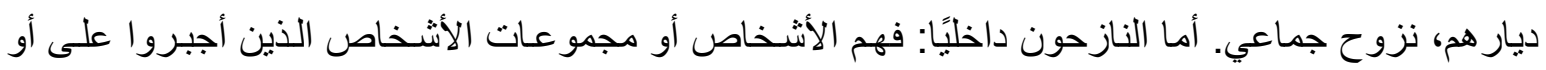

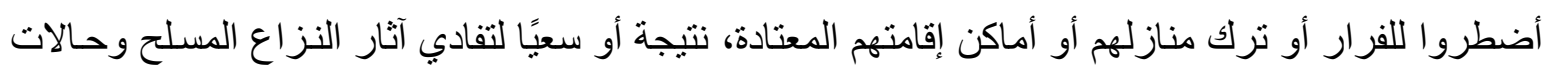
العنف المعدم، و انتهاكات حقوق الإنسـان أو الكوارث البشرية أو الطبيعية، والذين لـم يعبروا حدود الدولـة

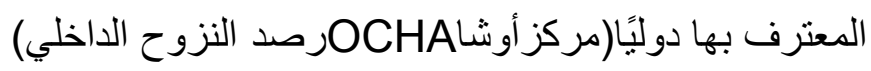
و عرف الباحث النازح- النازحون: هم الأشخاص أو الجماعات التي أضطرتهم الظروف، أو أجبروا

على ترك أماكن سكنهم أضطر ارًا بسبب التهديد بأنو اعه: الكوارث البيئية، الديني، المذهبي، الطائفي. الصراع النفسي Conflict: أطلق عليه (طه) "صر اع داخل النفس Intrapsychic " و هو الصـراع الذي يدور رحاه بين جوانب النفس الثناثة وهي الأناو الأنـا الأعلى و الهو، أو هو الصـر اع الذبي ينشـأ داخل النفس عندما يحبذ جانب منها أمرًا معينًا بينما يرفضه جانب آخر ، أو عندما تكون إمكانات الفرد محدودة ولديه أكثر من دافع ملح في نفس الوقت الذي لا يستطيع فيه إلا أن يشبع واحدًا فقط منها( طه، ب99 (،ص •r؟) 
يعر فه" عبد الغفار " بأنسه تعرض الفرد لقوى متسـاوية تدفعهه في وجهات متعددة بحيث يصبح عـاجزًا عن اختيار وجهة معينة، ويشـعر الفرد في مثل هذا الموقف بمشـاعر الضيق والتوتر لعجزه عن الاختيار(عبد

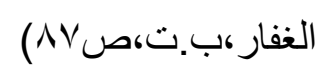
التعريف الإجرائي:الدرجات التي يحصل عليها المستجيب في تطبيق مقياسـا المخـاوف الثـاملة و الصـراع النفسي من أفر اد العينة الحالية.

\section{الأدبيات ودراسات سابقة:}

أدرك المشتغلون بالعلوم النفسية والاجتماعية والتربوية ومجال الارشاد والتوجيه النفسي " أن للنازحين العديد من المشكلات الاجتماعيـة والنفسية المتزايدة، فضـلا عن تغير في عـاداتهم وتقاليدهم وهم يواجهون

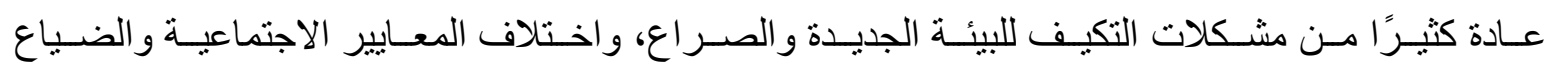

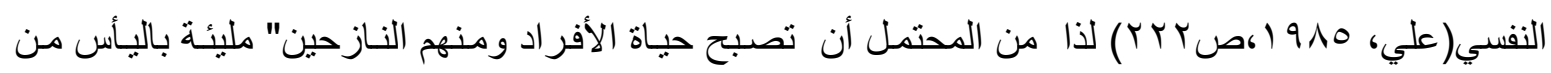

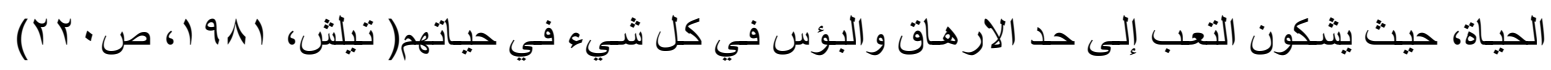

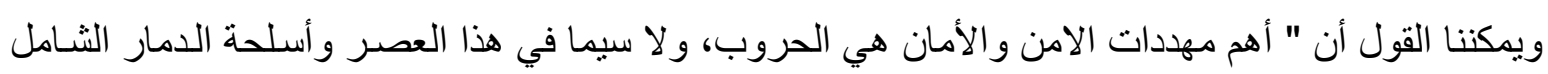
وما يصاحبها من خسائر في الارواح و الممتلكات وتعويق المدينة، وفقدان الأمن، فالحروب لا تسنتثي أحدًا في

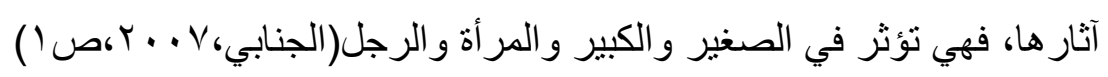
أصبح الإنسان في هذا العصر يواجه الظروف المعقدة كالحروب و النزاعات و الصر اع من أجل الحياة،

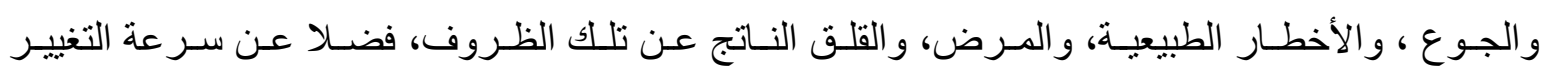

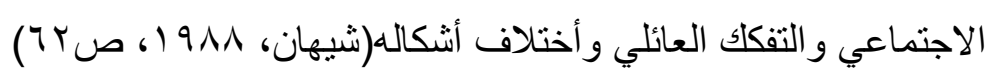

أن فقدان (النـازح) للـدم الاجتمـاعي، هو احساسـه بأنه لا يوجد من يهتم بـه أهتمامًا عميقا، وعوزه

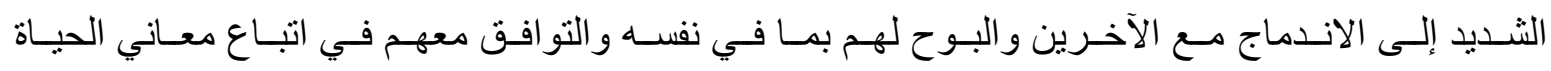

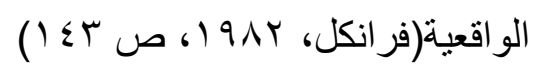

أن أي نزوح أو هجرة تترك آثارًا سلبية في نفوس المهاجرين أو النـازحين "الأطفال و البالغين"، مهـا كانت الظروف، قسرية، أو اختياريـة، وحتى عندما يعود النـازح خـارج مدينته في بلده أو المهاجر إلى بلد

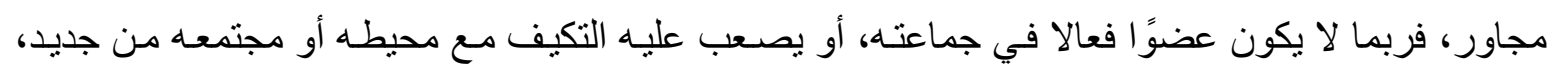

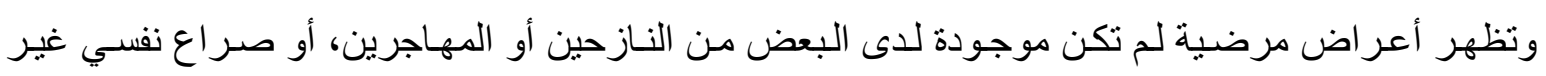

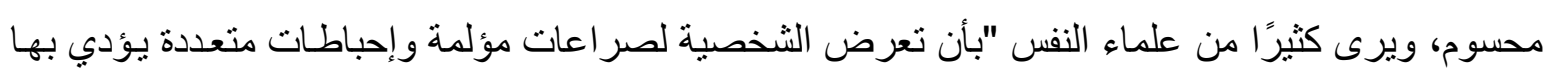
إلى سوء التو افق الثخصي و الاجتماعي وظهور العديد من مظاهر الاضطر اب النفسي، ممـا يمكن معـه القول بأن معرفة هذه الصر اعات والاضطر ابات والمتغيرات التي تحددها يعد مطلبًا أساسيًا لفهم هذه الاضطر ابات

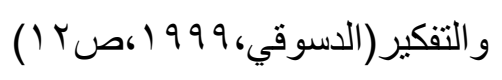




\section{المغاوفض"الفوبيا" الرهاب" مدفل جديد:}

أن الفوبيا ما هي إلا ردود أفعال مز اجية مرتبطة بـالقلق، فهم يفترضون أن الخوف يتحول لاشعوريًا

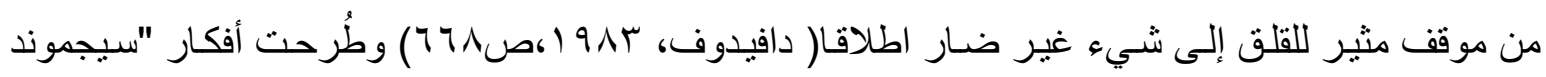
فرويد" عن الفوبيا في بدايات علاجه لحالة هـانز الصغير مداخل كثيرة حيث رأى "فرويد" في تبرير عملية الاستبدال هذه- أي بتحويل مصدر الخوف موضوع"داخلي" هو الخوف من الأب إلى شيء "خارجي" هو

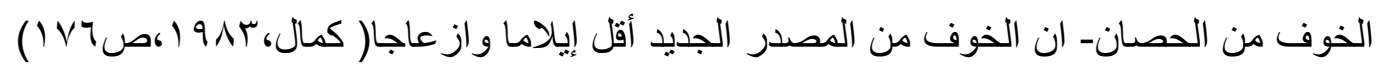

يـرى "أوتـو فينخلـ" أن الخـوف إذا تجدول للخـارج مـع هستيريا القلق، يصـبح فوبيـا، حيث يتجنب المو اقف المثيـرة للقلق في صسورة فوبيـا ملائمسة خارجيـة، فيتحول القلق لموضـوع خـارجي. وترى دورثي

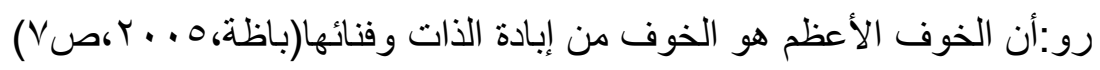
أن الفوبيـا خـوف شديد(مرضـي) مس أنشياء أو مو اقف نوعيـة لا حصـر لهـا حتى أن(إنجلثـو إنجلش) يشيران في معجمهما إلى فوبيا الفوبيا Phobophobia بمعنى الخوف المرضـي من الإصـابة بالفوبيا( طـه

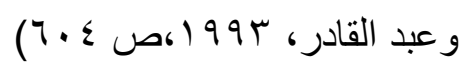

ويصاحب الفوبيا عدة أنواع مختلفة من القلق تسبب الازعاج وتؤدي إلى اضطر ابات الهلع التي تشبه

حالات الهوس، ولكن هناك فروق فردية في التحمل ( Eysenck,2000.p621 أما النظرية السلوكية Behavioral Theory فترى في بحوثها وجود دليل: يسجل قليل من الناس أنهم اكتسبوا اضطر ابات الخوف بطريقة مباثـرة خلال الخبرات المحدثة للخوف، ومن ناحيـة أخرى يقول

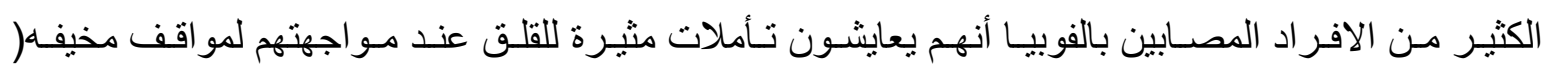

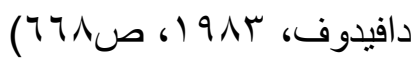
إن المخاوف هي في الو اقع مخاوف غير عقلانية، إذ لا حدود في الحقيقة لقائمة الأشياء والحالات التي قد تجلب الذعر و الخوف لبعض العصابيين، وتفسر المخاوف غير العقلانية في العادة، بأنها خبر ا قديمة مبكرة لا تبعث على السرور مع الثيء الذي نخشاه، ويفسره البعض الآخر باعتباره صر اعًا أو قلقًا في الثخصية

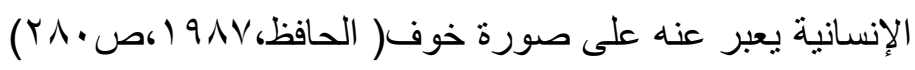

الخوف المرضي ضرب من الوسواس، إنه يتميز بالخشية من فكرة، أو شيء، أو وضـع معين، ويغزو

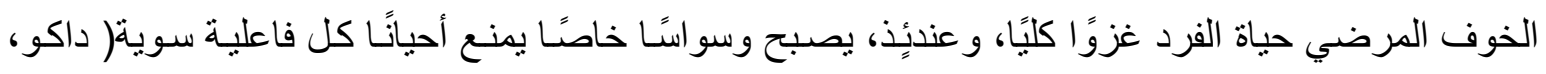

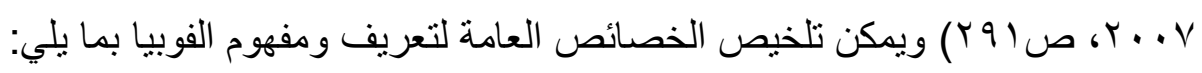
- يرتبط الخوف المرضي(الفوبيا) بموقف لا يمثل خوف حقيقي وموضوعي أو شديد للثخص. ـ مصدر الفوبيا أحيانًا من مثيرات بيئية خارجية، وأحيانًا من تفكير الثخص وتخيلاته حول ذاته وظروفه. ـ تتشـأ المخـاوف المرضية من مفـاهيم ومعتقدات وأفكار خاطئة ترتبط بموقف (مثير) الخوف، وبذلك فهي

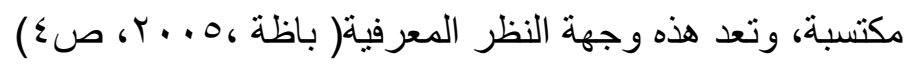




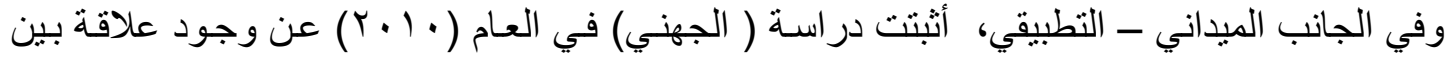

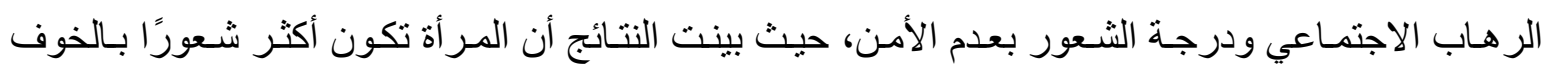
الاجتماعي مقارنة بالذكور، كذلك أن الاناث أقل شعورًا بالطأنينة النفسية مقارنة بالذكور، كذللك دلت الدراسـة

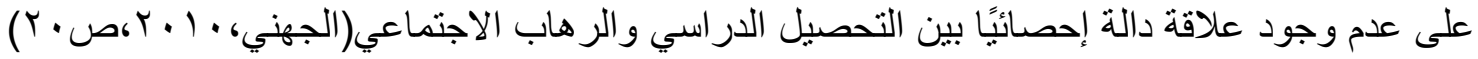

\section{الصراع النفي الثلفية النظرية:}

أن الصـر اع النفسي هي حالـة انفعاليـة غير سـاره قوامها الثـعور بـالحيرة والتردد و الضـيق والقلق تصيب الفرد عندما تتناز عه اتجاهات مختلفة ذات قوى متساوية بشـأن بعض دو افعه و أهدافه التي يسعى إلى إثباعهاو تحقيقها( القريطي ،919 (1، ص 7 × (1) لذا فأن الصراع داخل النفس شيء طبيعي وسوي، فكل منـا يكابده، هذا النوع من الصر اع بدرجاته ومستوياته المختلفة، شعورية، وكأن هذا الصر اع من سنة الحياة، لكن الفشل في حله هو الذي قد ينتج عنه مرض نفسي بمعنى أن المرض النفسي ينتج عن فثل في حل الصـراع داخل النفس البشـرية، لكن ليس كل صـر اع، وليس كل فثـل في حله ينتج بالضـرورة مرضيَا نفسيًا (طه،

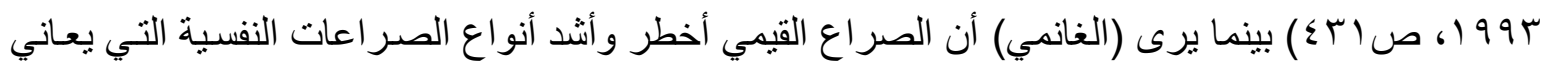
منها الفرد ، لأن القيمة نزعة نفسية معرفية يتعلمها الفرد من المجتمع وتتسم بالثبات في السلوك(الغانمي،

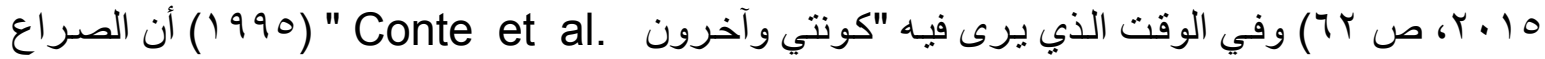
السيكوديناميPsychodynamic Conflict هو أكثر الأنواع انتشارًا لاى المر اهقين ويعد إنعكاسًا لوجود

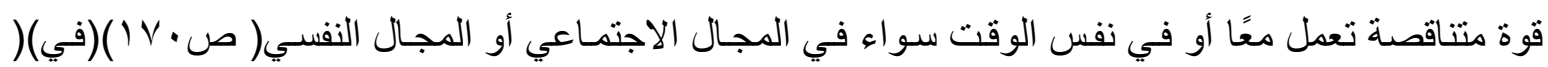
الدسوقي، 999 (،صل7)و على هذا فالذي يجعل الصراع الفعلي المرتهن بـالو اقع، صـر اعًا عصـابيًا هو العجز

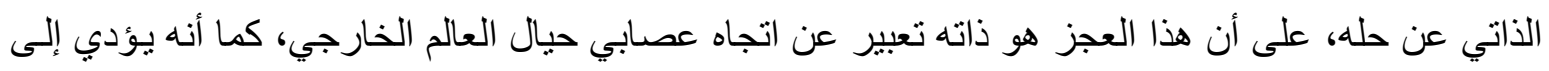

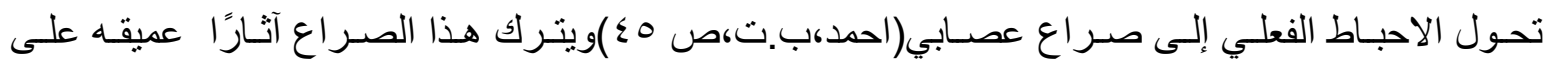
الأطفال مما يؤدي إلى إنهيار القيم الأسرية والعائلية التقليدية ( Corsaro,2011,p91 )

\section{هنمبمية البحث وإبمراكاته: \\ أولا: مجتمع البحث والعينة ثانيًا: أداتا البحث ثالثًا: التطبيق التهائي}

منهجية البحث:أعتمد البحث الحالي المنهج الوصفي الأرتباطي كونـه من المنـاهج الأكثر شيوعًا في التفسير العلمي المنظم لوصف ظاهرة أو مشكلة محدة، بالأمكان تصوير ها كميًا عن طريق جمع البيانات و المعلومات المقنــة عن الظـاهرة و إخضـاعها للار اسـة(Fraenkle\&Wallen,1993,p370) ) وتؤكد المعلومـات ان المنهج يعمل على إيجاد معاملات الارتباط استنادا على البيانـات المتحققة لأفر اد العينة البطش و أبو زينة 
أولا: مجتمع البحث والعينة: تَكون مجتمع البحث من النازحين من محافظة "نينوى" بـالعر اق إلى محافظـات كرستان العراق"أربيل وسوران" ومحافظة واسط" جنوب بغداد" ـ وبدأ النزوح للمحافظات بعد أحداث أحتلال

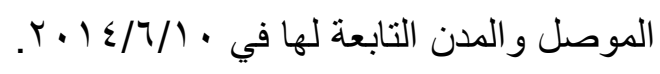

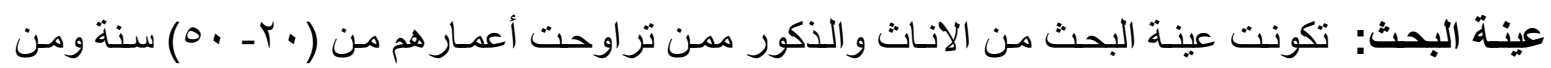
مختلف القوميات (العرب و الأكر اد) والأديان( المسلمين ، المسيحيين، الأيزيديين) و المذاهب ( الثيعة، السنة،

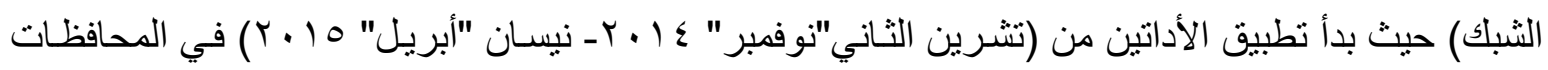

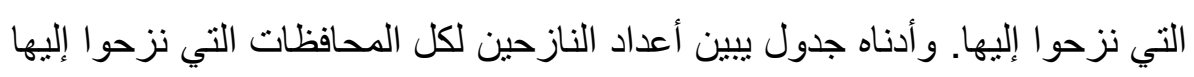
جدول(1) يبين أعداد أفراد العينة من النازحين

\begin{tabular}{|c|c|c|}
\hline أعداد العينة & المحافظات & ت \\
\hline rr. & اربيل وسوران "كردستان العراق" & 1 \\
\hline$v$. & واسط & $r$ \\
\hline$r \ldots$ & & \\
\hline
\end{tabular}

جدول(2) يبين عدد الذكور والاناث في العينة

\begin{tabular}{|c|c|c|}
\hline الجنس & اعداد العينة & ت \\
\hline ذكور & IV. & 1 \\
\hline \multirow[t]{2}{*}{ أناث } & $1 \%$. & $r$ \\
\hline & $\mu \ldots$ & \\
\hline
\end{tabular}

ـ المقياس الاول هو مقياس المخاوف الثاملة. إعداد آمال عبد السميع باظة. ـ المقياس الثاني هو مقياس الصراع النفسي. إعداد مجدي محمد الدسوفي. من خـلال الاطـلاع على الأدبيـات و الدراسـات المتعلقة بالموضـوع بالمصـادر الاجنبيـة والعربيـة تبنى

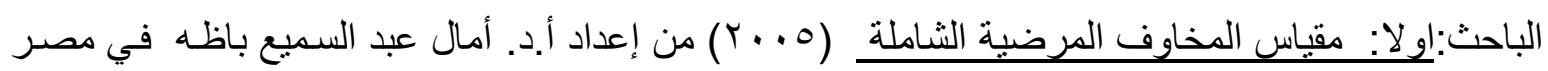
وكان يتكون من ( • آ) بنداً موزعة على خمسة أبعاد هي: البعد الأول: الخوف من المستقبل البعد الثاني: الخوف الخاص بالعلاقات الاجتماعية البعد الثالث: الخوف من المرض و الحوادث البعد الرابع: الخوف من الموت و الحساب البعد الخامس: الخوف غير المعروف المصدر

أعتمــ المؤلف على بعض النظريـات المفسـرة لنشـأة المخـاوف المرضـية، كإطـار نظـري وهــه النظريـات هي: النظريـة الجينيـة ، نظريـة التحليل النفسي، نظريـة الذات، نظريـة التعلم الاجتمـاعي، النظريـة السلوكية، النظرية المعرفية. ور أى مؤلف المقياس بعد مر اجعة النظريـات والآراء حول المخـاوف و الفوبيات المختلفة نم إعداد مقياسه بأبعاده الخمسة، حيث طبقه على طلبة( ذكور و وانـاث) كليـة التربية بأقسـامها العلميـة 


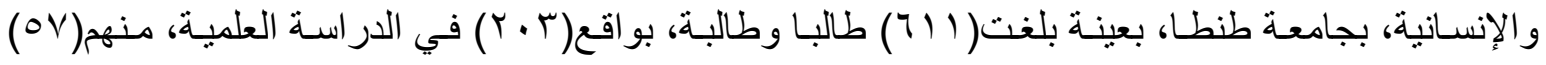

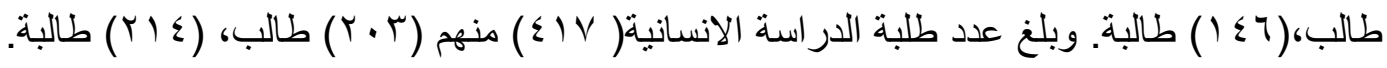

أتبـع المؤلف عدة خطوات لتصـيم وبنـاء وتقتنين المقيـاس منهـا الاطـلاع على المقاييس الخاصــة

بالمخاوف وكيفية تصنيف المخاوف تبعًا لارتباطها بموضوع محدد إلى مخـاوف عامـة غير محددة وأخرى محددة المثير، "مثلمـا قدم(فرويد) عن الخوف المرضي من الحيوانـات و المخـاوف غير معروفة المصدر،

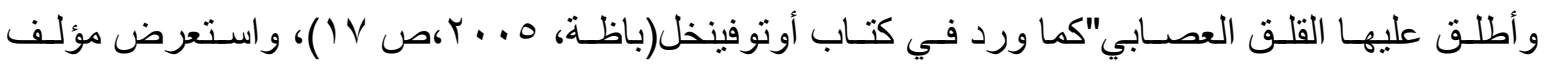
المقياس نموذج( ديفيد و اطسون Watson.D 1994 ) الذي وضـع الخوف ضمن قائمسة الوجدانات السـالبة الثـاملة، كما عرض ضمن مصـاحبات الأمر اض العقلية و النفسية في أبعـاد زمنية تنلاث وهو الخوف من الماضي و الحاضر و المستقبل.

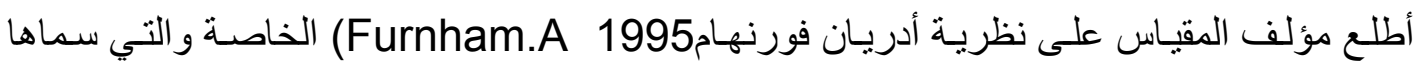
نظرية الاعتقادات عن الفوبيا Lay Theory وباستخدام اختبار تم بنائهه من المقابلات الكلينيكية الثخصية، وتحليل المحتوى، و السلوكية، و الأعر اض، و النشأة للفوبيا، ودمج "فورنهامFurnham" بين ستة وجهات نظر من النظريات:

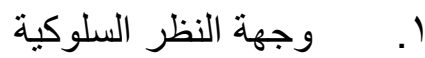

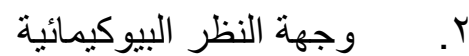
r. وجهة النظر التحليلية ع. وجهة النظر الجينية

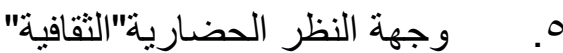
T. وجهة النظر المعرفية

حيث تبنى مؤلف المقياس وجهات النظر الستة وصمم مقياسـه بمجالاتهـأما المقياس الحسالي الذبي طبق على عينة عر اقية من النـازحين فتبنى مقياس( باظـه) وتم تقنينه على البيئة العر اقيـة، وأخزل مجالاته إلى ثلاثـة

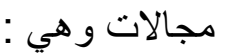

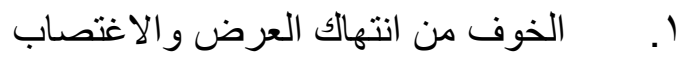

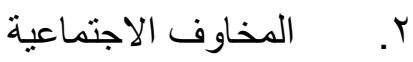

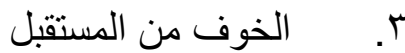

ثانيا: مقيساس الصراع النفسي: (1999) أعداد كونتي وآخرون Conte et al تعريب وتقنين أ.د. مجدي محمد الاسوقي. أعد الباحث مقياسه على وفق المجالات التالية : أ. منخفضو الصر اع النفسي ب. مرتفعو الصراع النفسي 
اعدت الفقرات باتجاهين الاول هو منخفضوا الصراع النفسي و الثاني هو مرتفعوا الصر اع النفسي، وبلغت فقر اته (ro) فقرة.

- استخرج الصدق الظاهري والصدق البنائي أو التكويني Construct Validity الصدق التجريبي Experimental Validity Factorial Validity

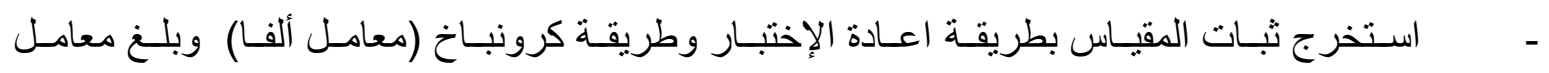

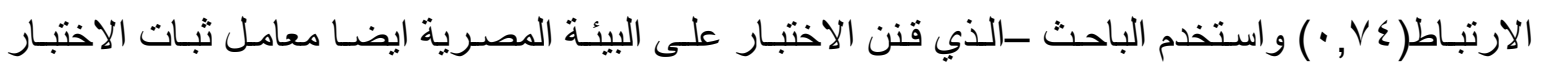

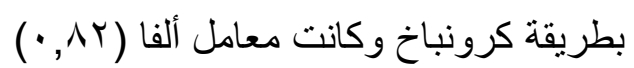
طبق المقياس على عينة من طلبة المدارس الثانويـة و الجامعة، بلغت ( . . V) طالب وطالبة، وكانت عينة الاناث( . . (r) و عينة الذكور( ( . ع). - أجرى الباحث الحالي حينما أستخدمه على النازحين العر اقيين بعض التعديلات على مقياسالصراع النفسي ليكون (صراع نفسي مرتفع، وصر اع نفسي منخفض). إجراءات التقتين على بيئة النازحين العراقيين:تم عرض المقياسين على مجموعة الخبر اء المختصين في علم النفس و الارشاد النفسي (جدول r) يوضح أسماء الخبراء. لغرض استخر اج صدق الخبراء للأداتين ومدى ملائمتهما لعينة البحث الحالي من النازحين.

Validity

الصدق الظاهري: بعد إستكمال الفقرات تحقق الباحث من الصدق الظـاهري للأداتين كل على انفر اد، وذلك

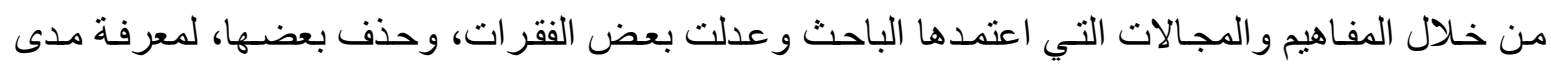

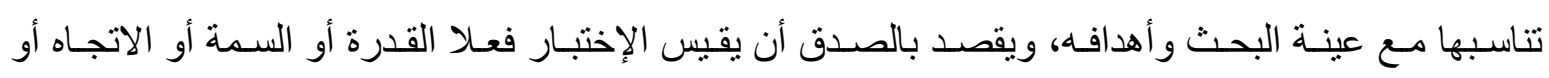

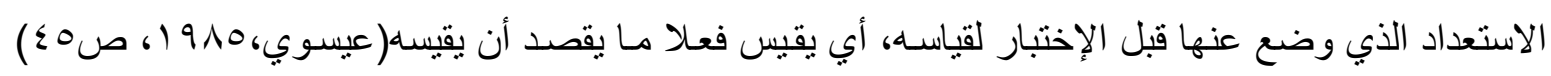
لذا يعد من الخصائص الضرورية والاساسية للاختبار ، وهي خطوة مهمة واساسية لابد من تو افر ها و التحري

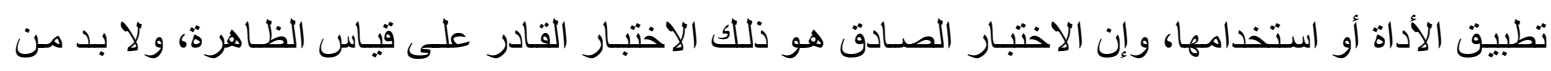
خطوة أخرى وهي "صدق الخبر اء" من خـلال عرض الاداة على لجنة من الخبر اء المختصين في مجال

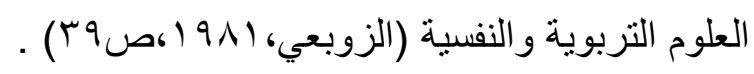

استخدم الباحث ايضا الصدق الوصفي أذ يشمل هذا النوع من الصدق على انواع أخرى إلا انها غالبـاً

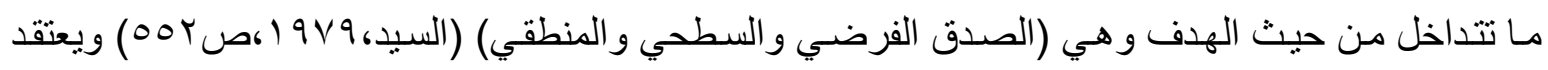
الباحث أن هذه الانو اع الثلاثة من الصدق تتحقق عند عرض المقياس على عدد من الخبر اء فضـلا عن اجر اء الباحث نفسه مع الاختبار

صدق الخبراء: من الخصـائص الاساسية للاختبار وجودته، ويعد خطوة مهمـة ورئيسـة، لابد من تو افر هـا

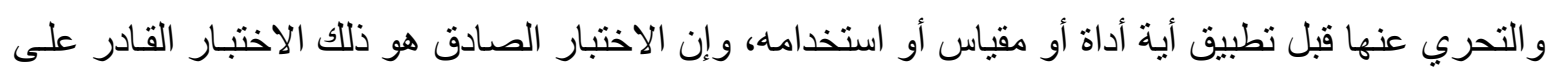


قياس الظاهرة، و لا بد من خطوة أخرى وهي "صدق الخبراء" من خلال عرض الاداة على لجنة من الخبراء

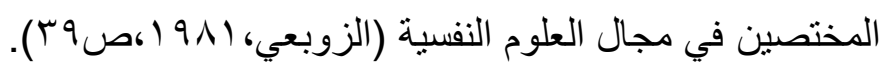

عرض المقياسين (المخاوف المرضية الثشاملة والصر اع النفسي) على عدد من الاسـاتذة ذوي الخبرة و الاختصـاص في مجـال علم النفس والارشـاد النفسي، وطلب مـن السـادة المحكمين، الحكم على صـحة ووضـوح الفقر ات، وكذلك مدى ملائمنهـا لعينـة البحث الحاليـة، وتعديل مـا يرونـه مناسبًا، أو حذف بعض الفقر ات، وتم إجر اء بعض التعديلات وحذف البعض الآخر، و أصبح : مقياس المخاوف الثناملة مكون من ب فقرة فقط ومقياس الصراع النفسي مكون من 17 فقرة فقط جلول( 3) يبين بأسماء الخبراء

\begin{tabular}{|c|c|c|c|c|}
\hline 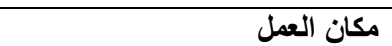 & التخصص & المرتبة العلمية & اسماء الخبراء & 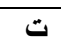 \\
\hline كلية|التربيةتللبنات - جامعة الكوفة & علم النفس & 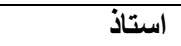 & د. باسم فارس جاسم الغانمي & 1 \\
\hline كلية التربية - جامعة البصرة & الارشاد النفسي & استاذ & د.عياد اسماعيل صالح & r \\
\hline كلية التربية -جامعة البصرة & الارشاد النفسي & استاذ استاذ & د.فاضل عبد الزهرة مزعل & $r$ \\
\hline كلية الاداب- جامعة بذاد & علم النفس & استاذ مساعد & د. عباس الاسدي & $\varepsilon$ \\
\hline كلية التربية ـجامعة واسط & علم النفس & استاذ مساعد & دـ. علي عبد كاظر عجه & - \\
\hline كلية||لتربية - جامعة|البصرة & الارشـادالنفسي & استاذمساعا & لد. عبد الكريم غالي محسن & 7 \\
\hline كلية||لتربية - جامعة|البصرة & الارشادالنفسي & استاذمساعا & د. عبد المحسن عبد الحي & $\mathrm{v}$ \\
\hline كلية|التربية - جامعة|البصرة & الارشادالنفسي & استاذمساعد & د. حامد قاسم ريشان & $\Lambda$ \\
\hline كلية|التربية - جامعة|البصرة & الارشاد/لنفسي & استاذمساعد & لد. محمود شاكر عبد الله & 9 \\
\hline كلية|التربية - جامعة|لبصرة & الارشاد/النفسي & استاذمساعد & لد.رياض ناصر رمضان & 1. \\
\hline
\end{tabular}

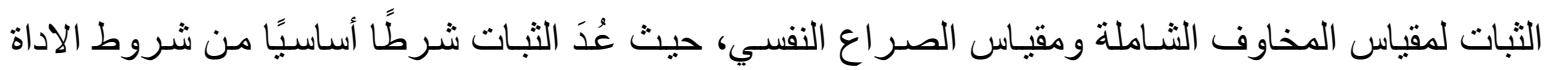

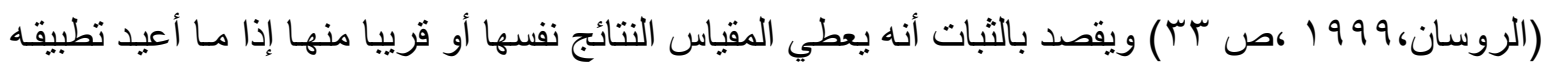

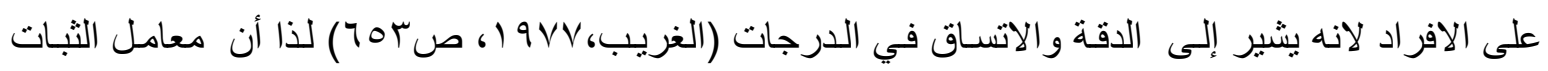
هو تقدير لمعامل الارتباط وكلما ارتفع هذا المعامل ازداد إتساق الاختبار في قياس ما صمم له أن يقيس (ملحم . (ror var...

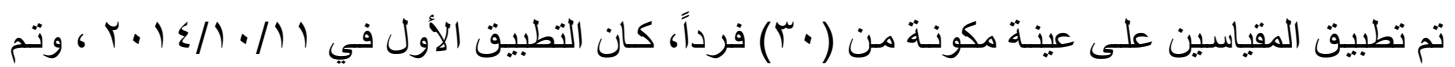

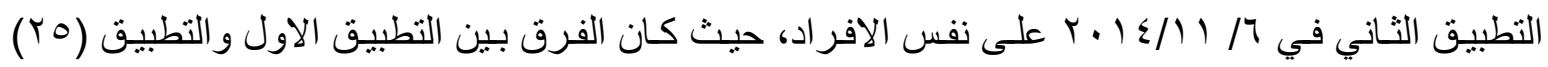
يوماً، وبعد تصحيح الإجابات الواردة في التطبيقين الأول و التناني تم استعمال معامل ارتباط بيرسون لإيجاد معامل الأرتباط بين نتائج التطبيقين الأول والثاني إذ بلغت قيمة الثبات بهذه الطريقة كما مبين في جدول(

جدول( 4 ( 4 ) يبين معامل الثبات للمقياسين

\begin{tabular}{|c|c|}
\hline معامل الثبات & المقياسين \\
\hline$\cdot, \mathrm{V4}$ & مقياس المخاوف الشاملة \\
\hline$\cdot, \mathrm{VA}$ & مقياس الصراع النفسي \\
\hline
\end{tabular}

تطبيق الأداتين : قام الباحث بالإشر اف على تطبيق المقياسين بنفسه من خلال التواصل مـع اسـاتذة في جامعـة

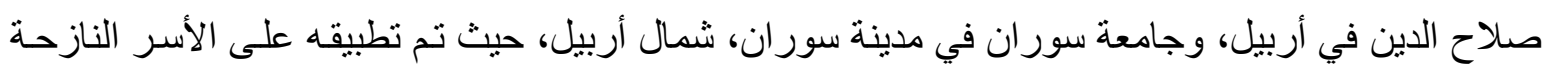


من نينوى مركز الموصل و الاقضية والنواحي والقرى التابعـة لمحافظة نينوى. أمسا أفراد العينـة التي كانت نازحة إلى محافظة واسط ومن محافظة نينوى و الاقضية و النواحي و القرى التابعة لها، فكانت منتشرة في مركز محافظة واسط" الكوت" وقضاء النعمانية و المدن الاخرى ومعظمه من المسلمين الثيعة. تصحيح الاداتين :فيما يتعلق بأداتي المخـاوف الثـاملة و الصراع النفسي ، صممت ثنلاث إختيار ات أمسام كل فقرة (تنطبق علي - تتطبق إلى حد مـا - لا تنطبق ) وكانت قيمـة كل بديل على التو الي (ثلاث درجات ـ درجتان - درجة واحدة).

نتانُه البمشث:

عرض وتفسير النتائج: لنقل أهداف البحث الحالي إلى حيز التطبيق تبنى الباحث عدد من الفرضيات القابلة

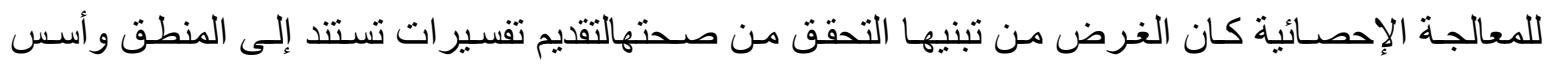
البحث العلمـي لتعليـل الظـاهرة المدروسـة والخاصـة بمخـاوف النـازحين و علاقتها بالصـر اع النفسي. و وبعد التطبيق أسفرت الدراسة الميدانية عن كم من البيانات تمت معالجتها باستخدام معالجـات إحصـائية تنسجم مـع بـع أهداف هذا البحث. ومن تللك المعالجات بعض مقاييس الإحصـاء الوصفي ( كالمتوسط الحسابي، الانحر اف المعياري، النسب المئوية). أمـا البعض الآخر فكان نوع من الاختبـار ات المعلمية كاختبـار الدلالة المعنويـة

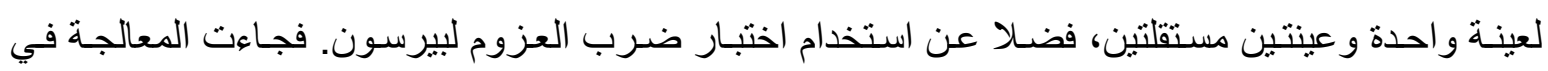

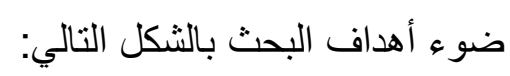

\section{الهدف الأول( قياس مستوى المخاوف لدى عينة البحث وفي ضوء متغير الجنس)}

لتحديد مستوى المخاوف طُبق مقياس المخاوف على عينة البحث البالغ حجمها ( . . ب) نـازح ونازحسة

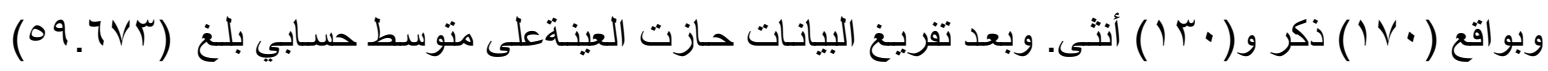

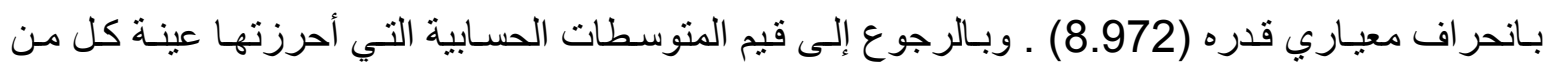

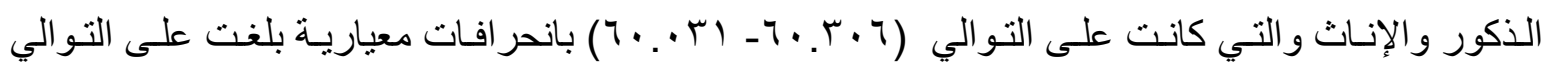

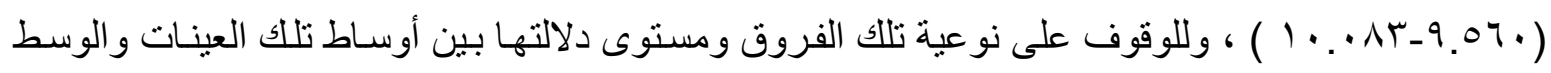
الفرضي للمقياس البالغ (52) قام الباحث بتحليل تلك البيانـات باستخدام الاختبـار التـائي لعينـة واحدة، فبلغت القيم التائيـة المحسوبة للعينـة ككل وللذكور والإنـاث على التو الي (14.812- 11.332- 9.085 ) و عند مقارنة تلك القيم بالقيم الجدولية عند درجات حرية تكون :

وبمستوى دلالـة ( 0.01 ) لاختبـار ذو نهايتين و البالغـة على التوالي (2.807، 2.834) نلاحظ أن جميع تلك القيم المحسوبة هي اكبر من القيم الجدولية الأمر الذي يشير إلى وجود فروق ذات دلائلة إحصائية عند مستوى ( 0.01) ، علما بان الفروق سجلت لصالح العينة كاملة ولكلا الجنسيين بمعنى أن العينة بمـا فيها

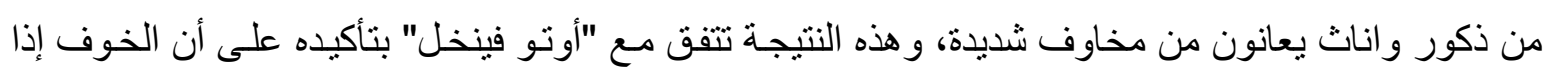


تجدول للخارج مع هستيريا القلق، يصبح فوبيا، حيث يتجنب المواقف المثيرة للقلق في صورة فوبيا ملائمـة خارجية، فيتحول القلق لموضوع خارجي. وكذلك تتفق مع ما طرحته دورثي رو بقولها: أن الخوف الأعظم هو الخوف من إبادة الذات وفنائها ، و الجدول ( 5) يوضح ذلك:

جدول (5)(يوضـح احجـام العيــاتوقيم المتوسطات والاتحر افـات المعياريـة والقيمةالتائيسة ودرجـات

الحرية والقيم الجدولية ومستوى دلالة الفروق بين عينات البحث والوسط الفرضي لمقياس المخاوف )

\begin{tabular}{|c|c|c|c|c|c|c|c|c|}
\hline دلالة الفروق & 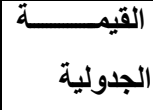 & الحرية & التيائية & 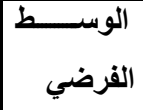 & الالاتحــــــــاف & 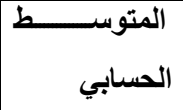 & حجمها & العينة \\
\hline \multirow{3}{*}{ 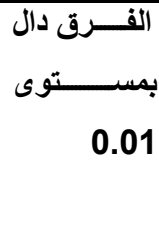 } & 2.807 & 299 & 14.812 & \multirow{3}{*}{ or } & $\overline{c \Lambda . q V Y}$ & $09.7 V r$ & "r.. & العينة \\
\hline & \multirow{2}{*}{2.834} & 169 & 11.332 & & 9.09. & $7 . .4 .7$ & IV. & عينة الأكور \\
\hline & & 129 & 9.085 & & $\overline{1 . . \wedge r}$ & $7 . .41$ & $1 \%$. & عينة الإناث \\
\hline
\end{tabular}

وفي ضوء قيمة الوسط الفرضي لمقياس المخاوف بلغ عدد المفحوصين الذين يعانون من ( مخاوف مرتفعـة) ( 245 ) نازح وبنسبة بلغت ( 81.66 \%)، في حين حصل أفراد العينة ممن لليهم مخـاوف منخفضـة على نسبة (18.33\% ).وفي ضوء متغير الجنس سجل كل من الذكور و الإناث ممن لديهم مخـاوف مرتفعـة نسب كانت على التوالي ( 35.66- 46 \% \% ( ) في حين حصل المفحوصين من كلا الجنسيين الذين لم تكن مخاوفهم مرتفعة على نسب هي على : (1) مه المخط ذان ه. $(7.66 \%$

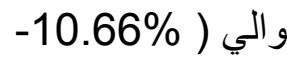
الت

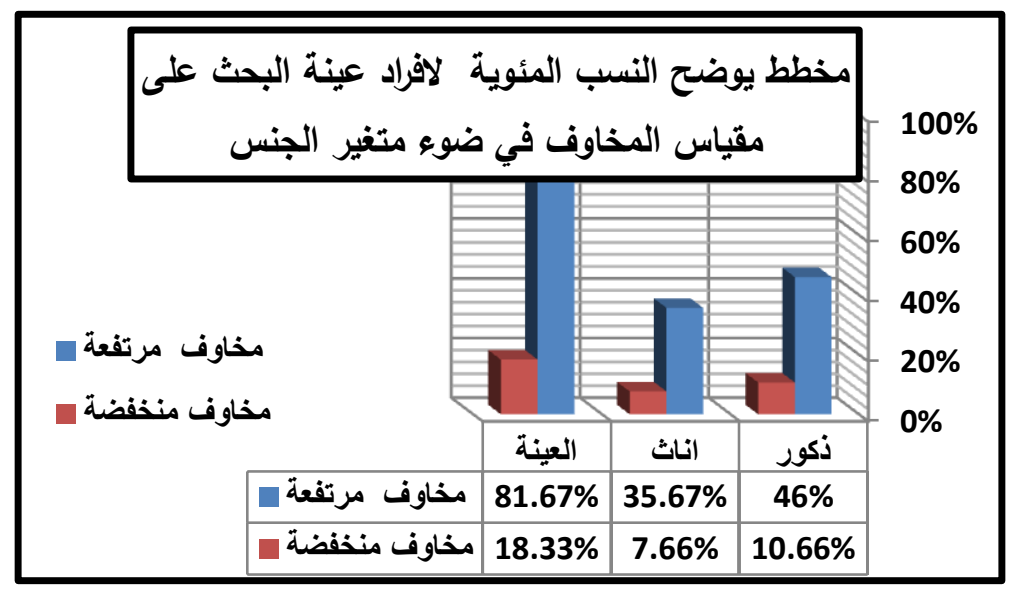

الهذف الثاني: ( قياس مستوى الصراع النفسي لاى عينة البحث وفي ضوء متغير الجنس) للكثف عن مستوى الصراع النفسي لدى عينة البحث قام الباحث بنطبيق مقياس الصر اع النفسي على عينة من النازحين المستهدفين بهذا البحث فبلغت قيمة المتوسط الحسابي للعينـة ككل ( 35.593) بـانحر اف معياري وقدره ( 6.191)، وفي ضوء متغير الجنس حصل النازحون و النازحات على متوسطات كانت على التو الي (34.371 -33.915) بانحر افات معياريـة بلغت على التو الي( 6.667- 7.349) ،وللوقوف على نوعية الفروق ومستوى دلالتها بين أوسـاط تلك العينات و الوسط الفرضي للمقياس البالغ (32) قام الباحث 
بتحليل تلك البيانات باستخدام الاختبار التائي لعينـة واحدة، فبلغت القيم التائية المحسوبة للعينة ككل وللذكور و الإنـاث على التو الي ( 10.064- 4.639- 2.969 ) و عند مقارنـة تلك القيم بـالقيم الجدوليـة عند درجات حريـة (299-169- 129) وبمستوى دلالـة ( 0.01 ) لاختبار ذو نهايتين والبالغـة على التو الي (2.807، 2.834) نلاحظ أن جميع تلك القيم المحسوبة هي اكبر من القيم الجدولية الأمر الذي يشير إلى وجود فروق ذات دلالة إحصـائية عند مسنتوى ( 0.01) ، علمـا بـان الفروق سجلت لصـالح العينة كاملـة ولكلا الجنسيين بمعنى أن النازحين من الذكور و الإناث لديهم صر اع نفسي مرتفع، وهي نتيجة منطقية كما أكدتها أدبيات علم النفس، و على هذا فالذي يجعل الصر اع الفعلي المرتهن بالو اقع، صر اعًا عصابيًا هو العجز الذاتي عن حله، على أن هذا العجز هو ذاته تعبير عن اتجاه عصابي حيال العالم الخارجي، كما أنه يؤدي إلى تحول الاحبـاط الفعلي إلى صراع عصابي( احمد،ب.ت،صنء ) و الجدول( 6 ) يوضح ذلك:

جدول ( 6 )

(يوضـــأحجام العينــات وقيمالمتوســطاتو الاتحر افاتالمعياريةوالقيمالتائيةودرجات الحريــة والقـيم

الجدولية ومستوبدلالة|لفروقبينعينات البحث والوسط الفرضي على مقياس الصراع النفسي )

\begin{tabular}{|c|c|c|c|c|c|c|c|c|}
\hline 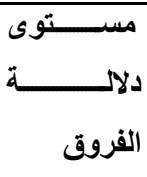 & الجدولية القيمــــة & الحرية & القائية & الفرضي الوســـــــــ & 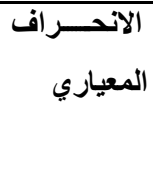 & الحسابي & حجمها & العينة \\
\hline الفــــق دال & 2.807 & 299 & 10.064 & \multirow{3}{*}{32} & 6. 191 & 35.593 & $\overline{\mu \ldots}$ & العينة \\
\hline \multirow{2}{*}{0.01} & \multirow{2}{*}{2.834} & 169 & 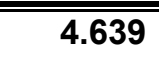 & & 6.667 & 34.371 & IV. & عينة الأكور \\
\hline & & $\overline{129}$ & 2.969 & & $\overline{7.349}$ & 33.915 & $1 \%$. & عينة الإناث \\
\hline
\end{tabular}

وفي ضوء قيمة الوسط الفرضي لمقياس الصراع النفسي بلغن عدد النـازحين مدن يعانون من (صراع

نفسي مرتفع) (193) ناز ح وبنسبة بلغت (64.33\%).في حين حصل أفراد العينة ممن لديهم (صر اع نفسي منخفض) على نسبة (35.67\% ). وفي ضوء متغير الجنس سجل كل من الذكور والإناث مدن للديهم (صر اع نفسي مرتفع) نسب كانت على التو الي ( 38\%26.33\%) في حين حصل النازحون من الذكور و الاناث ممن لايهم ( صر اع نفسي منخفض) على نسب هي على التوالي ( 18.67\% 17\%) ـ ـ و هذا مـا يوضحه المخطط (2 ) :

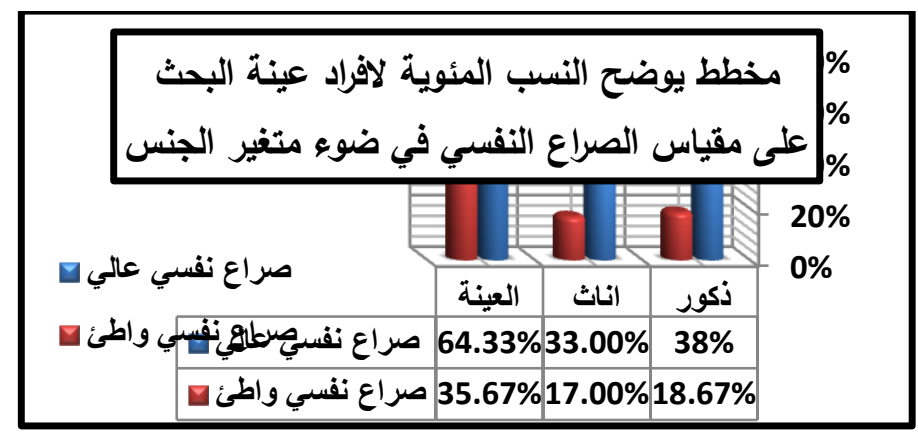


الهُف الثالثـ- (التعرف على نوعية الفروق ومستوى دلالتها بين أفراد عينة البحث على مقياس المخاوف وفي ضوء متغير الجنس)تم تحقيق الهدف في ضوء نتائج الفرض التالي:

الفرض الأول الذي يشير إلى أنهالا توجد فروق ذات دلالة إحصائية بين متوسط درجات الذكور ومتوسط درجات الإناث على مقياس المخاوف.)

إن نظرة فاحصـة إلى قيم المتوسطات الحسـابية والانحر افـات المعياريـة لنتائج النـازحين من كـلا الجنسيين تطالعنا بوجود اختلافات ضئيلة بينهما، ولغرض الوقوف على حقيقة تلك الفروق ومستوى دلالتها قـام الباحث بمعالجـة البيانـات المتجمعـة باستخدام المعالجـة الإحصـائية لاختبـار الدلالـة المعنويـة للفرق بين متوسطات العينات المستقلة، إذ بلغت القيمة التائية المحسوبة (2.895). وبمقارنة تللك القيمة بالقيمة الجدولية

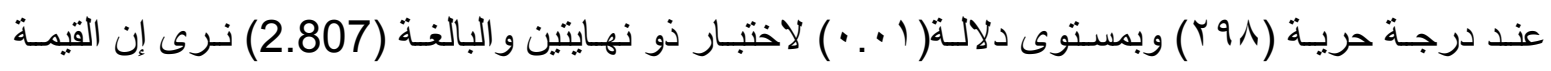
المحسوبة اكبر من القيمة الجدولية الأمر الذي يشير إلى وجود فروق ذات دلالة إحصسئية بين الجنسيين في مستوى المخاوف. وقد كانت الفروق من نصيب عينة الذكور و الجدول( 7 ) يوضح ذلك:

جدول (7)(يوضح اجحام العينات وقيم المتوسطات والانحر افات المعيارية و القيمة التائية ومستوى دلالة الفروق بين الجنسين على مقياس المخاوف )

\begin{tabular}{|c|c|c|c|c|c|}
\hline مستوى دلالة الفروق & القيمة التائية & الانحراف & المستوسطي & حجمها & العينة \\
\hline \multirow[t]{2}{*}{ الفرق دال عند مستوى I •. } & \multirow{2}{*}{2.895} & 9.09. & $7 \cdot . r \cdot 7$ & IV. & عينة الأكور \\
\hline & & $1 \cdot . \wedge r$ & $7 . . .41$ & $1 \pi$ & عينة الاناث \\
\hline & & & & & \\
\hline
\end{tabular}

الهذف الرابع- (التعرف على نوعية الفروق ومستوى دلالتها بين أفراد عينـة البحث على مقياس الصراع النفسي وفي ضوء متغير الجنس)تم تحقيق الهدف في ضوء نتائج الفرض التالي:

الفرض الثاني الذي يثير إلى أنه (لا توجد فروق ذات دلالة إحصائية بين متوسط درجات الذكور ومتوسط

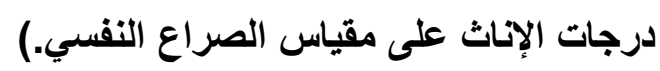

تطالعنا قيم المتوسطات الحسابية والانحر افات المعياريـة لعينة الذكور وعينـة الإنـاث بوجود اختلافات نوعية بينها، ولغرض الوقوف على طبيعة تلك الفروق ومستوى دلالتها، قام الباحث باختبار صحة الفرض وض الإس باعتماد المعالجة الاحصائية لاختبار الدلالـة المعنويـة للفرق بين متوسطات العينـات المستقلة، إذ بلغت القيمـة التائية المحسوبة بين متوسطات كل من النازحين و النازحات (6.706). وبمقارنة تللك القيمـة بالقيمة الجدولية

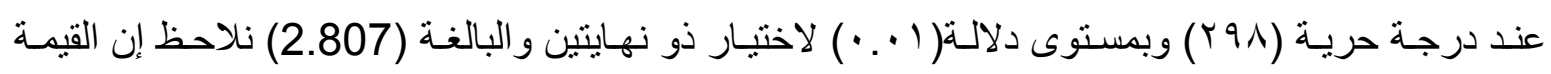
المحسوبة اكبر من القيمة الجدولية عند مستوى دلالة ( 0.01)، الأمر الذي يثير إلى وجود فروق ذاينين دات دلالة إحصائية بين الجنسيين في مستوى الصراع النفسي ، علما بان الفروق سجلت لصالح عينة الذكور. و الجدول( 8 ) يوضح ذلك: 
جدول( 8)(يوضح اجحام العينات وقيم المتوسطات والانحر افات المعيارية

والقيمة التائية ومستوى دلالة الفروق بين الجنسين على مقياس الصراع النفسين وصئ )

\begin{tabular}{|c|c|c|c|c|c|}
\hline مستوى دلالة الفروق & القيمة التائية & 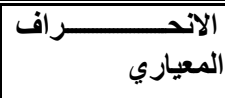 & 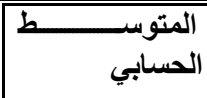 & حجمها & العينة \\
\hline \multirow[t]{2}{*}{ الفرق دال عند مستوى 1 +. } & \multirow{2}{*}{6.706} & 6.667 & 34.371 & IV. & عينة الأكور \\
\hline & & 7.349 & 33.915 & Tr. & عينة الإناث \\
\hline
\end{tabular}

الههف الخامس- (التعرف على نوع العلاقة ومستوى دلالتها بين متغير المخـاوف ومتغير الصراع النفسي لاى عينة البحث وفي ضوء متغير الجنس)تم تحقيق الهدف في ضوء نتائج الفرض التالي: الفرض الثالث والذي يشير إلى أنه (لا يوجد ارتباط ذو دلالة إحصائية بين متغير المخاوف ومتغير

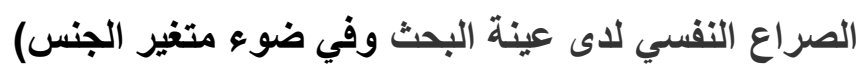
للكثف عن نوع العلاقة واتجاهها بين متغير المخاوف ومتغير الصراع النفسي لدى عينة البحث وفي ضوء متغير الجنس، قام الباحث بمعالجة البيانات المتجمعة باستخدام اختبار ضرب العزوم لبيرسون إذ بلغت قيم معامـل الارتبـاط المســوبة بـين المتغيـرين للـذكور والإنـات والعينـة ككل على التـو الي (0.5920.628- 0.524). وبمقارنة تلك القيم بالقيم الجدولية الخاصة بكل فئة عند درجات حرية هي على التوالي (128 - 1288- 298) وبمسـتوى دلالـة (0.01) لاختبـار ذو نهـايتين والبالغــة علـى التـو الي ( 0.1860.218- 0.165) ، نلاحظ أن جميع تلك القيم المحسوبة كانت اكبر من القيم الجدولية المحددة إزاء كل عينة، الأمر الذي يثير إلى وجود ارتباط موجب ودال إحصائيا بين متغير المخاوف ومتغير الصراع النفسي مئ لاى عينة البحث من النازحين ولكلا الجنسين، وتتقق هذه النتيجة مع أدبيات علم بالنفس تأكيدها على أن فقدان (النازح) للاعم الاجتماعي، هو احساسه بأنه لا يوجد من يهتم بـه اهتمامـا عميقا، وعوزه الثديد إلى الاندماج مع الآخرين و البوح لهم بما في نفسـه و التو افق معهم في اتباع معاني الحياة الو اقعيـة(فرانكل) والجدول (9) بوضنح ذلك:

جدول (9)(يوضح أحجام العينات وقيم معامل الارتباط ودرجات الحرية والقيم الجدولية ومستوى دلالة الارتباط بين متغير المخاوف ومتغير الصراع الاعل النفسي )

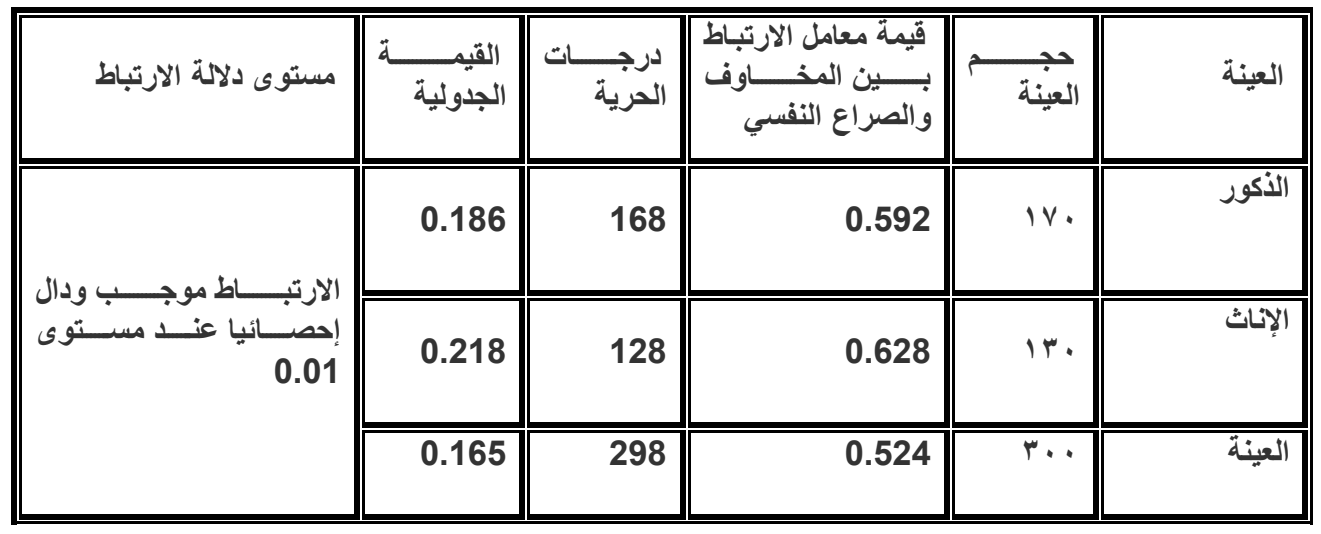


- إعداد بر امج نفسية و إرشادية للتخفيف من صدمة النزوح و استيعابها. ـ إعداد هيئة خاصة في وزارة الهجرة والمهجرين بالتعاون مع بعض المر اكز البحثيـة في الجامعات العر اقيـة لمتابعة النازحين ومشكلاتهم. ـ إعداد هيئة بحثيـة متخصصـة بالدر اسـات الطبيـة النفسية تضم متخصصين في الطب النفسي وعلم النفس و الارشـاد النفسي تختص بحالات النزوح ودر اسـة اضطر ابات مـا بعد الصدمة PTSD. حتى مـا بعد انتهاء أزمة النزوح و عودتهم إلى ديار هم بعد تحرير ها. ـ التعاون مع الجانب الدولي في جنيف وبعض الجامعات التي أسست مر اكز بحثيـة في مجال در اسـة أحوال النازحين.

\section{الإقتزحات: - (المت}

- إعداد در اسات أخرى نفسية واجتماعية تتعلق بمشكلات الاسر النازحة. - إعداد دراسة عن الثعور بالآمن النفسي لدى النازحين في المحافظات التي نزحوا اليها. ـ تكوين تجمعات لدى النـازحين "فكرة لم الثـمل" للأسر التي أنتقلت في محافظـات مختلفة لغرض إعـادة

\section{المصادرالعربية والاجنبية}

- احمد، سهير كامل(ب.ت) الصحة النفسية و التوافق، الكويت: السيف للنشر والتوزيع.

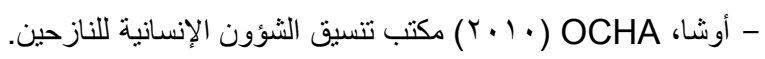

/http://www2.ohchr.org -

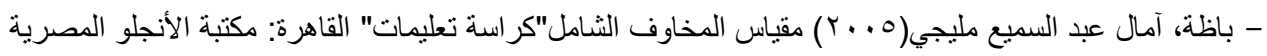

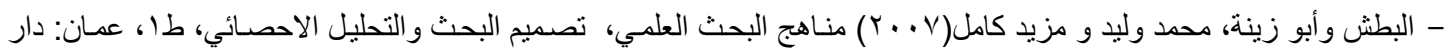
المسيرة للنشر.

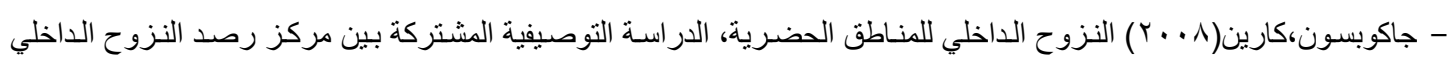

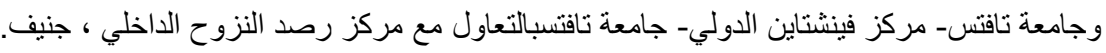

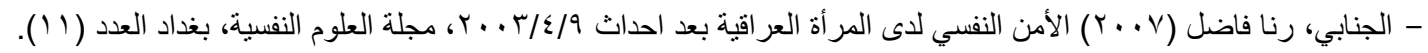

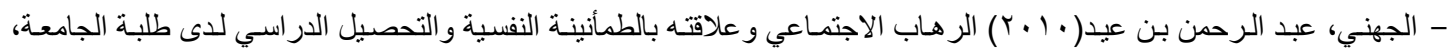

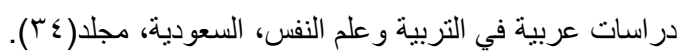

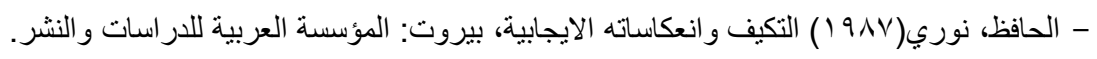
- دافيدوف، ليندا ل( بر9 (1) مدخل علم النفس، ترجمة سيد الطواب وآخرون، القاهرة: دار ماكجرو هيل للنشر.

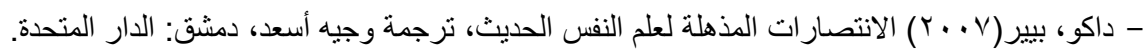
- الدسوقي،مجدي محمد(9991) مقياس الصراع النفسي، القاهرة: مكتبة الأنجلو المصرية. - القريطي، عبد المطلب أمين(991 (19) في الصحة النفسية، القاهرة: مكتبة الأنجلو المصرية. - عبد الغفار، عبد السلام(ب.ت) مقدمة في الصحة النفسية، القاهرة: دار النهضة العربية. - علي، يونس حمادي(910 1) مبادئ علم الديموغر افية، الموصل: مطابع جامعة الموصل. - عيسوي، عبد الرحمن محمد(910 (1) القياس و التجريب في علم النفس و التربية، القاهرة: دار المعرفة الجامعية. 
- الغانمي، باسم فارس(10 ( ب) الصحة النفسي وبعض أساليب المعالجة، القاهرة: مكتبة الأنجلو المصرية. - الغريب، رمزية (rاج (1) التقويم و القياس في المدارس الحديثة، القاهرة: دار النهضة المصرية.

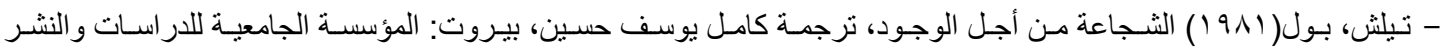
والتوزيع. ـ الزوبعي، عبد الجليل وآخرون( (191) ). الاختبار ات والمقاييس النفسية، الموصل: دار الكتب للنشر والتوزيع. - السيد، فؤاد البهي(9V9 (199) علم النفس الاحصائي، القاهرة: دار الغكر العربي.

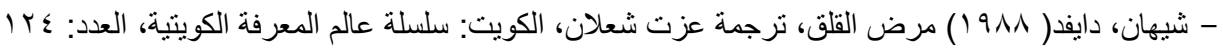
- طه، فرج عبد القادر و آخرون(ب99 (1) موسو عة علم النفس والتحليل النفسي،الكويت: دار سعاد الصباح. - ملحم، سامي محمد( · . . ץ) القياس والتقويم في التربية و علم النفس، عمان: دار المسيرة للطباعة و النشر. - ويتنج، أرنو ف (9VY ( ) مقدمة في علم النفس، ترجمة عادل الاشول و أخرون، سلسلة ملخصات شوم، القاهرة: دار ماكجرو هيل للنشر.

- Corsaro, A.William (2011) The Sociology of childhood, London; SAGE Publications, Inc.

-- Eysenck, Michael (2000) Psykologi, translet, Björn Nilsson, Kopenhagen; Narayan Press.

- Fraenkle, J.R.E.Wallen (1993) How to desing and evaluate research in education ( $2^{\text {nd }}$ ed)New York: McGraw Hill INC. 